\title{
The Chronological Cycle of the Bulgarians.
}

\section{I.}

The inscription of Chatalar has furnished a definite proof that the Bulgarian words in the Regnal List ${ }^{1}$ ) of early Bulgarian kings have a numerical meaning. That they represent numbers seemed, indeed, quite clear from the text, for the constant formula is: a liet (or lie $e^{t}$ ) emou (dilom trirem etc.). Oniy in one instance do we find instead: emou imia. Almost all the savants who have dealt with the document (Gil'ferding, Jireček, Kunik, Radloff, Géza.Kuun) have rightly assumed that we have to do with numbers. But there were serious difficulties in the way of their interpretation. It was evident that they could not be the Bulgarian equivalents of the regnal (or life) years which are given in Slavonic. The first two items show this. Avitokhol „lived“ (shit) 300 years; his successor Irnik "lived" 108 (or 150) years; but in the case of both liet emou dilom tvirem. If dilom twirem means 300, it cannot also mean, in any numerical system, 108 (or 150, as Jireček reads). Similarly Kur't reigned 60 years, Bezmier 3 years; but for both lie emou shegor vechem'. On the other hand Telets, like Bezmier, reigned 3 years, but in his case $\operatorname{lie}^{t}$ emou somor altem.

It is further to be observed that in every case the number is of the same type, consisting of two words, and the second word always ends in em (im) or om. One would naturally take them to represent units and tens (assuming the scale to be denary), and in that case it would seem that no numbers below 10 occur.

The interpretations which Kuun ${ }^{2}$ ) and Radloff ${ }^{3}$ ) attempted, with the

1) The text was first published by A. Popov, Obzor khronographov russkoi redaktsii, I, 25 (1866), to which I have not access. It was reprinted by A. Gil'ferding, Istoriia Serbov i Bolgar (Sobranie sochenenii, I) 20-1; this is the text which I have used. Jireček gives a transliterated text, Geschichte der Bulgaren, 127. A Latin translation by Jireček is printed in Géza Kuun, Relationum Hungarorum etc. II, 11-12, and is repeated in Marquart, Chronologie der alttïrkischen Inschriften (1898) 72-3. I have given an English translation in Gibbon, ed. Bury, VI, App. $9 . \quad$ 2) Loc. cit.

3) Dit altiürkischen Inscìriften der Mongolei. 
help of Turkish comparisons, are quite unsatisfactory, and Marquart, seeing this, revived the old conjecture of Tomaschek ${ }^{1}$ ) that the glosses are not numerical. "Es können also in diesen Glossen überhaupt keine Zahlwörter stecken, sondern nur, wie schon Tomaschek vermutete, Charakteristiken der Regierungen und Persönlichkeiten der einzelnen Chane". ${ }^{2}$ This conclusion completely threw over the data of the document; it would compel us to suppose that liet emu is throughout an error, and that the solitary emu imia preserves the truth.

Fortunately, an inscription of Omurtag, found a few years ago at Chatalar, near Preslav, and edited by Uspenski in the publication of the excavations of $\mathrm{Aboba}^{3}$ ) has come to the rescue. This important stone furnishes the date of the founding of Preslav. The last words of the inscription are:

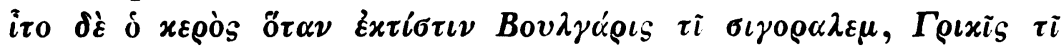

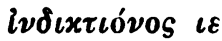

The only $15^{\text {th }}$ indiction that fell during the reign of Omurtag was current from Sept. 1821 to Aug. 31822. We learn therefore that part of this twelve-month was coincident with part of a year which the Bulgarians designated $\sigma i \gamma_{0} \rho \lambda \varepsilon \mu$. Now this word is actually (as Uspenski did not fail to observe) sound for sound the same as one of the glosses in the Regnal List: shegor alem. The clear inference is that these glosses supply absolute chronological dates and represent an ancient Bulgarian system of chronology. It is an interesting problem to determine what this system was.

For the sake of the reader's convenience, I will give a transliterated text of the Regnal List, using Greek letters to represent the numerals.

\section{List of Bulgarian Khans.}

Avitokhol zhit liet $\tau^{\prime}$. rod emou doulo. a liet $\mathrm{e}^{\mathrm{M}}$ dilom tvirem. Irnik zhit liet $\rho^{\prime}$ i $\eta^{\prime}$ lie ${ }^{t}$ ro ${ }^{d}$ emou doulo. a liet emou dilom tvirem. Gostun namiestnik syi. $\beta^{\prime}$ lie $e^{t}$ ro $^{d}$ emou ermi a lie emou dokhs trirem. Kourst $\xi^{\prime}$ lie $^{t}$ drbzha. ro ${ }^{d}$ emou doulo. a lie $^{t}$ emou. shegor vechemb. Bezmier $y^{\prime}$ liet . a rod emou dulo. a lie ${ }^{t}$ emou shegor viechem

sii $\varepsilon^{\prime}$ kъnAzb drъzhashe knAzhenie obonu stranou dunaia.

$\operatorname{lie}^{t} \varphi^{\prime}$ i $\varepsilon \iota^{\prime}$ ostrizhenami glavami. i potom pride na stranou Dunaia Isperikh knzb tozh ${ }^{\mathrm{d} e} \mathrm{i}$ doselie.

Esperik ${ }^{k n z b} \xi^{\prime}$ i odino lieto rod emou doulo. a liet emou verenialem.

1) Zeitsohrift f. d: Bsterr. Gymnasion, 28 (1877) 683.

8) 0 p. cit 98. pl. CXVIII).

3) Izvjestija russk. arch. Inst. $\nabla \mathrm{Kplje}, \mathrm{X}, 1905$, 545 sqq. (cf. Album, 
Tervels $x^{\prime}$ i $\alpha^{\prime}$ lie $e^{t}$ ro $^{d}$ emou doulo. a lie emu tekouchetem. triremb. [ - ] $x^{\prime}$ i $\eta^{\prime}$ liett. ro ${ }^{d}$ emou doulo. a lie ${ }^{t}$ emou dranshekhtemb. Sevar $\varepsilon^{\prime}$ liet. ro ${ }^{d}$ emu dulo a lie ${ }^{t}$ emou tokhalstom.

Kormisoshb. $\xi_{l}^{\prime}$ liet $^{t}$. rod emou vokilb. a lie emou shegor tvirimb.

siizhe kñzı izmieni ro $^{d}$ doulor rekshe vikhtunt.

Vinekh $\xi^{\prime}$ liet. a rod emou oukilb emou imA shegoralemb. ${ }^{1}$ )

Telets s $\gamma^{\prime} \operatorname{lie}^{t}$ ro emou ougain a lie $^{t}$ emou somor. altem.

i sii inogo rad.

Oumor. $\mu^{\prime}$ dnii, ro ${ }^{d}$ emou oukilb. a emou dilomb toutom.

The entry in which shegor alem occurs happens to be the one entry in which imia takes the place of lie $e^{t}$ We can now unhesitatingly correct the error.

I pointed out in $1898^{2}$ ) that Vinekh must be the same khan who is called $\Sigma \alpha \beta i \nu 0 s$ by the Greek writers Theophanes and Nicephorus. This conclusion. was independently reached by Marquart about the same time. ${ }^{3}$ ) The List places Vinekh before Telets and gives him 7 years, whereas from the Greek sources it appears that Sabinos was set up after the death of Telets. Marquart has therefore inferred that Telets and Vinekh have been transposed in order, in the Regnal List. I will proceed on the assumption that Vinekh should succeed Telets, and we shall find that the assumption is confirmed by our results.

Telets led the Bulgarians against an Imperial army and suffered a severe defeat on June 30 , in a year which Theophanes ${ }^{4}$ ) and Nicephorus ${ }^{5}$ ) give as indict. 1 . Theophanes mentions that the day of the week was Thursday, and this enables us to fix the year with certainty as 763. The deposition and death of Telets were the direct consequence of the defeat, so that we may probably place them and the elevation of Sabinos in July-August 763. Now the year of Vinekh $=$ Sabinos was shegor alem. It is hardly conceivable that this can mean anything but the year of his accession. Assuming this to be so, we have a sliegor alem year partly coinciding with July-Aug. 763, separated by an interval of about 6io years from another shegor alem year which coincided partly with Sept. 821 - Aug. 822. This at once suggests that the Bulgarians reckoned their chronology by a cycle of 60 years. The inference is confirmed by another datum of the List. The year

1) Ms. imAshe goralemb, corr. Kunik

2) Gibbon, VI, Appendix 9, p. 547.

3) Chronologie, 74.

4) Ed. De Boor 433, under A. M. 6254. In this case, the indiction 15 right, and the $A$. M. wrong.

5) Hist., ed. De Boor 70.

By «ant. Zeitschrift XIX 1 u. 2 .

!) 
of Kur't is shegor vechem. If this, as I assume, means his year of accession, then, since he reigned exactly 60 years, the year of his successor, Bezmier, ought to be the same; and so it is. Similarly the years of the mythical Avitokhol were $300=$ five 60 -cycles, and both he and his successor have the same year dilom tvirem.

Moreover, if we assume that the second word of each gloss (which always terminates in -em or -om) represents a ten, there appear to be not more than six different decads, namely: tvirem (tvirem', tvirim'), vechem' (viechem', ouch[et]em), alem (alem'), ekhtem' '), al'tom, toutom. (I leave it open at present whether altem is to be identified with alem or with al'tom). The assumption that the second word is a decad is supported by, the numerical system in the Old Turkish Inscriptions, where the unit precedes the decad; e. g. tokuz jägirmi $=9.20$. But it is to be observed that this does not mean 29; it signifies ('neun auf zwanzig') 19 as W. Bang has demonstrated. ${ }^{2}$ ) Now it is noticeable in regard to the numbers in the list that units never occur alone; they are always followed by a decad. With a chronological cycle, divided into decads, this is comprehensible. As the years 11-20 were "twenty"years, 21-30 "thirty"-years, and so forth, it was obviously convenient to quote the years $1-10$ as "ten"-years; e. g. to refer to the year 5, not as 5 but as 5.10 (just as 15 was 5.20 ).

What was the character of the Bulgarian official year? was it solar or lunar? The fact with which we start is that the year shegor alem was current in July-August A. D. 763, and again during some part of A. D. 821, Sept. 1-822, Ang. 31. If the years were solar, this would be impossible. If they were lunar (354/5 days), as 60 lunar years $=$ c. $\left.58^{\mathrm{y}} \cdot 78^{\mathrm{d}}(\text { solar })^{8}\right)$, it is clear that the same cyclical year, in which July-Aug. fell in 763, would be recurrent during Sept.-Nov. in 821. This satisfies the data; the cycle was lunar.

It is well known that the chronological system of the Chinese, dating from very ancient times, is based on a sixty-year cycle.") The Turkish inscriptions of Orkhon have confirmed the statement of the Chinese annals that the Chinese imposed their calendar upon the Turks,

1) Or shektem. The text has dvanshekhtem, and the division of the words must be left open.

2) See his Vorwort to Marquart's Chronologie der alttürkischen Inschriften. His demonstration is accepted by Marquart, also by Radloff, Hirth and Barthold (see in Radloff, Die alttürkischen Inschriften, $2^{\text {to }}$ Folge, 1899)

3) Reckoning, like the Arsbs, 19 years of $354 \mathrm{~d}$., and 11 of $355 \mathrm{~d}$., in 30 years.

4) The classical work on the Chinese calendar is Ideler, Utber die Zeitrechnung der Chinesen, Abh. (hist.-phil.) d. k. Ak. d. W. zu Berlin, 1837. 
at least for official use ${ }^{1}$ ), and the date seem to have been about A. D. 586. $)$ But there is no reason for supposing that this calendar was transmitted to the Bulgarians. We shall see, in the course of this investigation, that the Bulgarians did not systematize their chronology till after their settlement south of the Danube, at a time when influence from .Central Asia was out of the question, and in the second place their calendar differed essentially from the Chinese, inasmuch as they had no method of intercalation to harmonize from time to time the lunar with the solar periods. On the other hand, it seems probable that the use of 60 as a capital number (like our 100) may go back far into the common antiquity of the Eastern Turks and the Bulgarians.

The use of a lunar year, without periodic intercalations, raises another question. Did the Bulgarians compute time by lunar years before they systematized their chronology in the $7^{\text {th }}-8^{\text {th }}$ centuries? or may it be that they adopted for their official chronology the lunar years of the Hijra? This is by no means impossible. I may point to the remarkable evidence in the Responsa Nicolai, as to the introduction of Arabic books among the Bulgarians (libri profani quos a Saracenis abstulisse ac apud vos habere perhibetis). But, in any case, as, in examining the chronology, it will be necessary to equate the Bulgarian lunar years with Anni Domini, it will be a great practical convenience to assume that those years concurred with the years of the Hijra. For example, A. H. 206 was current from June 6821 to May 26822 , and this included Sept.-Nov. 821 which fell in a shegor alem year. In the same way, July-Aug. 763 fell in A. H. 146. By taking then (merely for the propose of computation) A. H. 146 to coincide with shegor alem, we shall reach results which can in no case be more than a few months astray, and it is obvious that, our data being what they are, we could not hope to attain to more than such approximate accuracy.

In order to compute the dates of the Regnal List, it is not essential to know the meaning of the decad-numerals, so long as we can determine their cyclical order. But it is necessary to determine in what years the decad-dates fell. Now as we know the year in which shegor alem was current, we should at once know when alem was current if we knew the value of shegor. Fortunately the List sup-

1) See Thomsen, Inscriptions de l'Orkhon dęchiffrées, Mém. de la soc. finnougrienne, V (Helsingfors, 1896), 172-7. Hirth, Nachworte zur Inschrift des Tonjukuk (in Radloff, Die altt. Insch. der Mongolen, $2^{\text {to }} \mathrm{F}$. ), 116 sqa.

2) Deguignes, Hist. générale des Huns, I, 2, p. 404. 
plies us with the means of determining shegor as one of two numbers. Bezmier's accession year was shegor vechem, he reigned three years, Kur't succeeded him in vereni alem. It is patent that if shegor meant any number less than 8 , Kur't would have acceded in a vechem year. shegor can only be 8 or 9 ; if it is 8 , vereni is 1 ; if it is 9 , vereni is 2. We must, therefere, adopt one of these alternatives-as a working hypothesis. I will assume that shegor is 8 , and we shall subsequently find confirmation of this assumption.

I do not propose to compromise my investigation by any etymological comparisons with Turkish or other languages (otherwise the comparison shegor: Turk säkiz 8 might be held to furnish a presumption for the equation of shegor with 8). Gil'ferding, Kuun, and others have attempted to explain the Bulgarian numerals by means of Magyar, Turkish, aud other tongues. Their suggestions, quite unconvincing, led to absolutely no results. My method is to examine the List in the light of its own evidence, and seek external aid only from some of the statements of Greek chronicles, relating to the eighth century. I will make no linguistic assumptions, but follow, as Plato says, ö $\pi 0$ c $\ddot{\alpha} \nu \delta \lambda \delta^{\prime} \gamma \circ \ddot{\alpha} \gamma \eta$. Linguistic may afterwards deal with the conclusions.

For the interpretation of the List, then, I lay down the following hypotheses:

1. The Bulgarian numerals represent the accession-dates of the khans. ${ }^{1}$ )

2. Of the two numerals which signify the date, the second numeral is a decad; and a number like 1.20 means not 21 but 11 .

3 . The system of chronology is a cycle of 60 years.

4. The years are lunar, and there is no intercalation.

5. Shegor $=8$.

Further, in order to facilitate computation, the Bulgarian lunar year will be treated as concurrent with the corresponding $\mathrm{A}$. $\mathrm{H}$.

But before we enter on our investigation of the chronology, it is necessary to make some critical remarks on the text. A cursory examination shows that the regnal years of the khans bave in some cases suffered corruption. Kormisosh came to the throne in 8. tvirem. If his predecessor Sevar reigned only 5 years (as the text has), the year of his accession would have been 3. tvirem. But his year was tolh al'tom. To pass from one decad to the year 8 of another decad, he must have reigned more than 8 years. Unless therefore we adopt the extremely unlikely alternative that al'tom is a mistake for tvirem, we

1) The abbrevation lie $e^{t}$ before the Bulg. numeral, in the text, stands thertfore for lieto (sing.). 
are obliged to suppose that $\varepsilon^{\prime}$ is an error for a higher number (e. g. $\left.\varepsilon \iota^{\prime}=15\right)$. An exactly similar inconsistency meets us in the case of Gostun. In general, I assume, as a matter of principle, that the Bulgarian years of accession, written in full, are correct, and that, in cases of inconsistency, the error is to be sought in the Slavonic numerals representing the regnal years or elsewhere.

Again we know from Theophanes (sub A. M. 6211) that Tervel was still alive in A. D. 718-9. Between that year and A. D. 760 when Telets came to the throne, there is no room for the 28 years assigned by the List to an anonymous ruler and the 17 years assigned to Kormisosh, even without making any allowance for the reign of Sevar. This proves that the text is wrong, and either the regnal years are widely astray or some of the reigns are out of their proper order. We have already seen that Telets and Vinekh are transposed; and we must be prepared to consider transposition, as well as corruption of numerals, as a possible source of error.

The Ms from which the scribe of our text copied seems to have been illegible just after the entry of Tervel's reign. His accession year is followed by another numeral, tvirem. A whole entry seems to have been omitted with the exception of the last word; and the name of the khan following has dropped out.

It is important to observe that the regnal years are given as round numbers, as if each ruler had reigned so many years without odd months. It must be inferred that the regnal years are not original data; had they been originally recorded, the months would have been noted. The accession years formed the original record, and from them the regnal years were inferred by mechanical counting. The sole exception is the last khan of the List, Umor, who reigned 40 days. We may conjecture, with some probability, that the List dates from the time of Umor's successor. We may also consider it possible that it was originally written in Greek and that the Slavonic text is a translation from the Greek. We know, by the evidence of the old Bulgarian stones, that before the introduction of the Slavonic alphabet in the second half of the ninth century, Greek was the Schriftsprache of the Bulgarians. The Bulgarian names of the cyclical years would have been written in Greek letters, as in the Chatalar inscription.

II.

There is no difficulty in determining the cyclical order of four of the decad-numerals. The year of Bezmier was shegor vechem, and it was 3 years before vereni alem, $\therefore$ vechem is the decad immediately 
before alem. The year of Kormisosh is shegor tvirem, and it was 20 $(3+17)$ years before shegor alem, $\therefore$ tvirem is the second decad before alem. The year of Umor shows that tutom was the decad immediately following alem. Thus we get the order: tvirem, vechem, alem, tutom.

It seems probable that al'tom came next before tvirem. For Sevar came to the throne in tokh al'tom, and, if we accept $\varepsilon \iota^{\prime}$ as the simplest correction of $\varepsilon^{\prime}$, reigned for 15 years, up to the year segor trirem. If so, al'tom is the decad before toirem, and the remaining decad ekhtem precedes altom. This determination, depending on a conjectural correction of a numeral, is uncertain, but we shall find that some confirmation will be forthcoming and we will adopt it provisionally. Accordingly we determine the cyclical order as

alem, tutom, ekhtem, al'tom, tvirem, vechem.

Since shegor alem =A. H. 146, alem = A. H. 148, and we at once get the following table of decad years.
tutom
A. H. 158 A. D. $774 / 5$
98 A. D. $716 / 7$
38 A. D. $658 / 9$
alem
vechem
A. H. 148 A. D. $765 / 6$
A. H. 88 A. D. $706 / 7$
A. H. 28 A. D. $648 / 9$
A. H. 138 A. D. $755 / 6$
A. H. 78 A. D. $697 / 8$
A. H. 17 A. D. $639 / 40$

trirem

\begin{tabular}{|c|c|c|}
\hline trirem & al'tom & ekhtem \\
\hline A. H. 128 A. D. $745 / 6$ & A. H. 118 A. D. $736 / 7$ & A. H. 108 A. D. $726 / 7$ \\
\hline $\begin{array}{lr}\text { A. H. } 68 \text { A. D. } 687 / 8 \\
\text { A.H. } 8 \text { A.D. } 629 / 30\end{array}$ & A. H. 58 A. D. $677 / 8$ & A. H. 48 A. D. $668 / 9$ \\
\hline
\end{tabular}

The text indicates a division of Bulgarian history into two periods, the point of division being the crossing of the Danube, which fell in the reign of Esperikh. We may begin with the first period, in which the record of the List is partly mythical.

We know from Greek chronicles that Esperikh (Asparuch) who led his people across the Danube lived in the seventh century. His year was vereni alem $(=1$. alem, as we saw), and the only year of this designation that can come into consideration is that which corre sponds to A. H. $19=$ A. D. 640 (Jan. 2-Dec. 20). Bezmier's year, shegor vechem, = A. H. 16 virtually coincides with A. D. 637. Kur't reigned a full cycle and his year, likewise shegor vechem, partly concurred with A. D. 579. His predecessor Gostun acceded in dokhs tvirem, and therefore (as we saw above) his regnal years cannot be 2, for in that case his year would be 6. vechem. The simplest correction would be (as in Sevar's case) to read $\beta \iota^{\prime}$ instead of $\beta^{\prime}$, which would make dokhs $=6$ and Gostun's year concur partly with A. D. 567. It 
is possible however that the true correction is somewhat more complicated, for the regnal years of Irnik introduce another difficulty.

Irnik's year is dilom tvirem. He reigned (the text has "lived", but the years of his "life" are obviously taken as regnal years) 108 years, so that he has passed partly into the borders of myth. But his accession in a tvirem year and his follower's accession in a tvirem year are incompatible with 108 regnal years. 6. tvirem +108 would give 8. vechem. It will not answer here to correct 108 by substituting 118 , for 118 would give shegor tvirem. The explanation of the error must be that an intervening khan has fallen out. Either an entry has been completely omitted before Gostun, or else Gostun and another khan who succeded him have been rolled into one, by the omission of parts of both entries. The cyclical year of Irnik's death could be determined if we knew the value of dilom. Now the year of Umor is dilom tutom, and as Vinekh, his predecessor, reigned 7 years and acceded in shegor alem, dilom means 3. Now a reign of 108 years beginning with 5. twirem gives 3. altom as the date of its termination. The successor of Irnik, accordingly, reigned from 3. altom to 6. tvirem i. e. 13 years. If the original text were of this form

Gostun. namiestnik syi. [ $\left.\gamma \iota^{\prime}\right]^{2} e^{t} r^{d}$ emou *. a lie emou * (=3) al'tom.

* . namiestnik syi.] $\beta \iota^{\prime}$ lie $e^{t}$ ro $^{d}$ emou ermi. a lie emou dokhs trirem. the corruption would be easily accounted for. But the omission of an entire entry before Gostun is perhaps almost as likely. ${ }^{1}$ )

Equating our results with Anni Domini, we get the years of accession as follows:

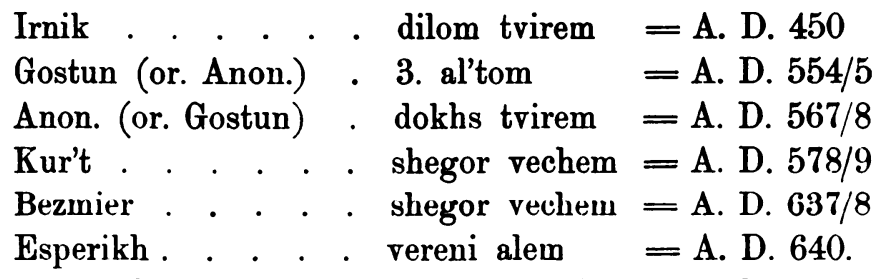

The year of the legendary Avitokhol, whose regnal years were 300 (= 291 solar years nearly) would correspond to A. D. 159.

Is is certainly remarkable that for Irnik's accession we get a date which is approximate to the death of Attila (A. D. 453) and the dissolution of the Hun empire (A. D. 454) which made the Bulgarians independent. Marquart's suggestion ${ }^{2}$ ) that the mythistorical Irnik of

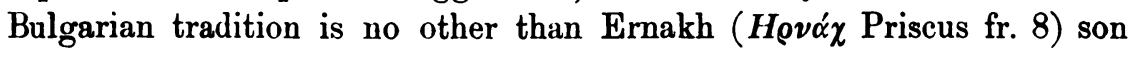

1) There were thus 6 princes before Esperikh. The text refers to them as "these 5 princes". 5 is therefore an interpolation.

2) Op. cit. $75-6$. 
of Attila, who withdrew to the neighbourhood of the mouths of the Danube after the defeat of the Huns, is well worth considering. The question lies beyond my present scope. But in any case the fact that we have determined Irnik's accession year ${ }^{1}$ ) so close to such an important event in Bulgarian history as the collapse of the Hun power, may be taken as a confirmation of our results.

The migration of the Bulgarians from their home north of the Danube into Mosia is marked by the author of the List as a dividing era in Bulgarian history. He observes that the total number of years during which "these [five]") princes" (scil. Avitokhol-Bezmier) ruled beyond the Danube was 515. Taking the text as it stands, we have the sum $300+108+2+60+3=473$. To reconcile the figures, Jireček proposed $\rho^{\prime}$ i $\nu^{\prime}$ (150) instead of $\varrho^{\prime}$ i $\eta^{\prime}$. for Irnik and this emendation seems to have been widely accepted. Our investigation of the Bulgarian dates puts this reading out of court (for if Irnik reigned 150 years, the termination of his reign would have fallen in dilom tutom, and there would be no room for his successors). If we take the corrections which I have tried to establish, we have $300+108+$ $13+12+60+3=496$. There is still a deficit of 19 years. I conclude that the received interpretation of the 515 years is incorrect.

Indeed it seems to be obvious that this number covers the whole early period up to the year of the crossing of the Danube, and, notwithstanding the expression "these [5] princes", includes the years of Esperikh in which he was still north of the Danube. For there is no reason to suppose that he migrated in the year of his accession. And so the difference between 515 and the sum of the previous reigns 496 enables us to determine the regnal year of Esperikh in which he crossed the Danube. His regnal years north of the Danube were 19.

We are now in a position to solve the question, in what year did tho cyclo bogin? What was the Bulgarian era? And the answer.

1) It may also be observed that our alternative date for the accession of Gostun 554/5 would correspond to Marquart's theory that Gostun (a Slavonic name) is the same as $K \varepsilon \lambda \alpha-\gamma \alpha \dot{\alpha} \tau \eta S_{S}$ who is mentioned in Menander fr. 6. Marquart actually places his reign in $554 / 5$ (p. 80), but in his interpretation of the List (p. 75) gives the date as 614/5, and offers no explanation of this discrepancy. His transposition of Bezmier before Kur't is certainly wrong, and if Bezmier, as he thinks, was a Slav, how does he account for the fact that he belonged to the Bulgarian family of Dulo? In general, Marquart's chronology (Irnik 464-613, Gostun 614-5, Bezmier 616-8, Kur't 619-78), which rests on the erroneous view that Irnik's 108 years should be corrected to 150 , is far from the mark. His suggestion that Avitokhol means Attila has some plausibility.

2) See above p. 135, noto 1 . 
furnishes a striking corroboration of our results and justification of our hypotheses. The decisive event in Bulgarian history was the migration which led to the permanent settlement in Mœsia, and it stands designated as an era in the Regnal List. It is thus marked out as the erent which is likely to have served as a starting point for the chronology. To prove that the Bulgarian chronological era actually was the crossing of the Danube', the necessary condition is that the date of this event should mark the beginning of a new decad; and if it fulfils this condition, its claim must be considered established. Now as Esperikh's year was vereni alem, his $19^{\text {th }}$ year expired in the year tutom; so that the crossing of the Danube is fixed to $\frac{\text { tutom }}{\text { vereni ekhtem }}$ - the point at which a new decad begins. We cannot regard this as an accident; there were nine chances in ten against such a result. ${ }^{1}$ )

The year tutom =A. D. 658/9 (June 9 - May 28), and vereni ekhtem = A. D. 659/60 (May 29 - May 16), so that A. D. 659 is the date of the Bulgarian migration and the beginning of the chronological cycle. We have hereby obtained the value of the decad numerals: ekhtem $=10$, al'tom $=20$, trirem $=30$, vechem $=40$, alem $=50$, tutom $=60$.

The new date for the Bulgarian migration disagrees with the received view, which places that event later, in the reign of Constantine IV. This view is based on the statements of Theophanes and Nicephorus which are derived from a common source. Theophanes (sub A. M. 6171, ind. 1) records that in this year (A. D. 679) $\tau \grave{o} \tau \tilde{\omega} \nu$

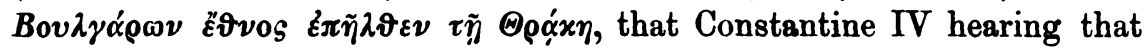

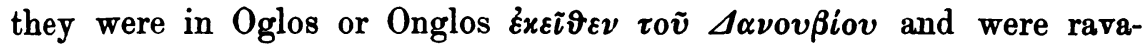
ging the provinces sent an expedition, was defeated, and concluded a peace. Into this annalistic statement he inserts a digression on "the ancient history of Onogundurs, Bulgars, and Kotragoi" and relates the legend of the five sons of Krobatos, of whom the third, Esperikh, crossed the Dnieper and Dniester and occupied Oglos between the

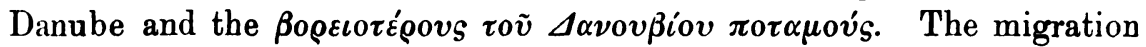
of Esperikh from beyond the Dnieper is of course as mythical as the dispersion of the sons of Krobatos, for the Bulgarians had certainly lived in the neighbourhood of the Lower Danube since the $5^{\text {th }}$ century. But historical matter is embedded. It is obvious that Krobatos or Krovat is the same as Kur't of the Regnal List; and we need hardly doubt

1) This result confirms the hypothesis that shegor $=8$. For if the chronology were calculated on the assumption that shegor $=9$, the crossing of the Danube would fall in 2 . ekhtem. 
that Esperikh was, as the legend says, Kur't's son. The date which Theophanes gives for the death of Krovat and the migration is the

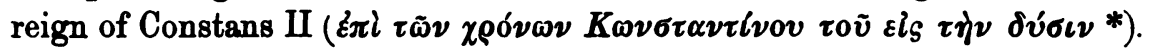
Kur't's death actually happened (Regnal List) in the reign of Heraclius, but the legend, associating it closely with the migrations, moves it forward into the reign of Constans, evidently because the historical event which underlay the migration-story belonged to the reign of Constans. Such an event is evidently Esperikh's occupation of Oglos. Now this occupation of Oglos meant the crossing of the Danube; it was the first stage in the conquest of cis-Danubian Bulgaria. The chroniclers did not understand this; they thought that Oglos was on the far side of the Danube; and modern historians have accordingly placed the migration from the north to the south of the Danube at a later date. Jireček makes it an immediate consequence of the defeat of Constantine IV in 679. "Die Bulgaren, die Ohnmacht der Byzantiner erkennend, siedelten noch in demselben Jahre auf das rechte Donauufer über." 1) But the stronghold of Oglos (it was a fortified place, not a district cp. Theoph. $\left.\delta \chi v v_{\rho} \omega \mu \alpha \pi \rho \circ \lambda \varepsilon \chi \vartheta \varepsilon v\right)$, lay, as we now know, on the right bank of the Danube. It has been shown by archaeological inquiry that the large earth fortifications at S. Nikolitsel, near the ancient Noviodunum (a place of great strategic importance) are of Old Bulgarian origin, and that the place fully corresponds to the description which Theophanes and Nicephorus give of the situation of Oglos. It is in fact almost certain that the place is the same as that which was called $\tilde{\eta} \mu \iota x \rho \grave{\alpha} \Pi_{\varepsilon \rho \iota \sigma \vartheta \lambda \alpha ́} \beta \alpha$ in later times. $\left.{ }^{2}\right)$

The Greek and the Bulgarian evidence, therefore, agree perfectly. The Greek date for Esperikh's occupation of Oglos is the reign of Constans II, the Bulgarian date for the movement across the Danube is A. D. 659. How soon the Bulgarians began to spread themselves beyond the Dobrudzha and gain a hold over Mœsia is another question. Probably not till after 679 .

We now come to the second part of our document, the list of cis-Danubian princes, and we are met on the threshold by an incon-

1) Op. cit. 129.

8) See Shkorpil, Prilozh. II, 568-60, in Aboba (cit. supr.). Cp. p. 517. For the notice of the settlement of Aspar-hruk son of Chubrat" in the island of Peuke, in the Geography of Psendo-Moses, see Marquart, op. cit. 88, and Westberg. Beitr. zar Klärung orientalischer Quellen über Osteuropa, in Izv. imp. Ak Nauk (St. Petersburg) XI. 5. 312 (1899). The writer, as Westberg points out, seems to be contemporary (7th cent.). 
sistency in the text. Esperikh is said to have reigned $61 \mathrm{y} ., \therefore$ as he acceded in 1. alem, the year of his successor should be 2. alem. But Tervel's year is tek vechem ${ }^{1}$ ), which nust be prior to 698 (as vechem $=697 / 8), \therefore$ Esperikh cannot have reigned so long as $61 \mathrm{y}$.

Again Tervel's regnal years must also be erroneous. The latest year in which he can have come to the throne is 696/7 (supposing $t e k=9$ ). We known from Theophanes that the earliest possible year for the close of his reign is A.D. 718/19, which corresponds to 2. ekhtem. Thus he must have reigned at least $23 \mathrm{y}$., and there must be error in the $21 \mathrm{y}$. assigned to him by the text.

We have already noticed that there is no room for the anonymous reign of $28 \mathrm{y}$. between Tervel and Sevar. Further, the text gives tvirem immediately after the notice of Tervel and this shows that the notice of another prince has been omitted, plainly because the scribe's copy was illegible here.

A satisfactory solution of these difficulties can be found by assuming that the order of the reigns has been transposed, and that the two anonymous princes whose accession years were tvirem and dvansh ekhtem really preceded Tervel. $\left.{ }^{2}\right)$ Thus:

[-] $x^{\prime}$ i $\eta^{\prime}$ liet. ro ${ }^{d}$ emou doulo. a lie emou dransh ekhtem.

[- $\boldsymbol{\vartheta}^{\prime}$ lie ${ }^{t}$. ro ${ }^{d}$ emou doulo. a lie emou] tvirem.

Tervel $x^{\prime}$ i $\alpha^{\prime}+$ lie$^{t}$. ro ${ }^{d}$ emou doulo. a lie ${ }^{t}$ emou tek vechem.

Then we get

Esperikh, acc. 1 alem, regn. 21 ann., A. D. $640-660 / 1$

Anon., acc. 2 ekhtem, regn. 28 ann., A. D. $660 / 1-687 / 8$

Anon., acc. trirem, regn. 9 ann., A. D. $687 / 8-696 / 7$

Tervel, acc. tek vechem $\quad$ A. D. 696/7-

and we have to read $\varkappa^{\prime} \mathrm{i}$ odino, instead of $\xi^{\prime} \mathrm{i}$ odino, for Esperikh's regnal years. $\left.{ }^{3}\right)$

I have assumed that tek vechem $=9$. vechem. My reason for this assumption is that if Tervel came to the throne in that year and died

1) Tekouchetem, the corruption in the text, can be explained by supposing

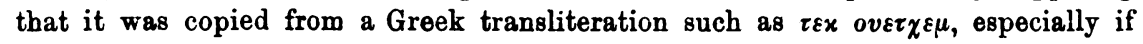
the er happened to have been written above the line.

2) The fact that the numbers admit of this reconstruction depends on the assumption that ekhtem precedes al'tom, and supports that assumption, which was suggested by the accession year of Sevar.

3) It is curious that Marquart (op. cit. 74), for quite different reasons, arrived at the conclusion that "wir haben für Esperich 21 statt 61 Jahre zu lesen"; his date for this ruler is $679-699$. 
in 3. ekhtem $=719 / 20$, we get $24 \mathrm{y}$. for his reign and this involves only the very slight change of $\Delta^{\prime}$ for $A^{\prime}$ in his regnal years. ${ }^{1}$ )

Sevar acceded in tokh al'tom and, as already suggested, the easiest solution (1) is to suppose that tokh al'tom $=3$. al'tom and that he reigned $15 \mathrm{y}$. ( $\varepsilon i^{\prime}$ for $\left.\varepsilon^{\prime}\right)$. If so these remains an interval of $10 \mathrm{y}$. between him and Tervel, and we must suppose that another reign has fallen out (that of a khan who acceded in 3. ekhtem and reigned till 3. al'tom). Otherwise (2) we might protract Tervel's reign till Sevar's succession in A. D. 729/30, making him reign 34 years (which involves the emendation $\lambda^{\prime}$ i $\delta^{\prime}$ ). The problem does not admit of a definite solution, for we have no independent data to furnish a control, and our reason for preferring one hypothesis to another is no more than the greater facility of one textual restoration compared with another. For historical study, the question is of little importance, as our knowledge of Tervel's immediate successors is a blank.

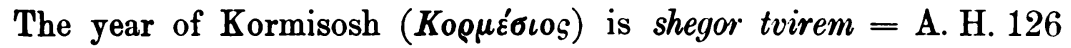
=A. D. 743 Oct. $25-744$ 0ct. 12 . He reigned 17 years $^{2}$ ), so that his death and the succession of Telets should fall in 5. alem. The year of Telets is given as somor alem (as we must evidently restore for altem), and here a difficulty encounters us. We have already admitted the claim of another numeral, dilom, to signify 5. The two claims are, on the face of the text, equally valid. Vinekh came to the throne in 8. alem, and reigned 7 years, $\therefore$ his successor's year should be 5 . tutom. His predecessor reigned 3 years, $\therefore$ his year should be 5 . alem. But the text gives in the one case dilom, in the other somor. The claim of somor must give way, because the results which we obtained by assuming that dilom $=5$ fully bear out the truth of that hypothesis. The solution must lie in the circumstance that the $3 \mathrm{y}$. of Telets were

1) I have, of course, experimented with the obvious hypothesis that the regnal years of Esperikh and Tervel were interchanged and that $\mathrm{T}$. reigned $61 \mathrm{y}$. This would imply that $T$. acceded in 2 . ekhtem and died in 3 . ekhtem. We have then (1) to take tek $=2$ and restore ouchetem as ekhtem (a much less probable restoration); we have (2), since dvansh ekhtem is the year of T.'s successor, to interpret dvansh as 3, whereas tokh al'tom, Sevar's year, is most probably 3. al'tom; and (3) we have to make the extremely unlikely supposition that $x^{\prime}$ i $\eta^{\prime}$ has been substituted for $\iota^{\prime}(10)$. Moreover (1) the gloss tvirem remains unexplained. The only thing that might be said in favour of this hypothesis is that Suidas (sub Bovidyopol) speaks of Tervel as already regant in the time of Constans II. But this statement is far more likely to rest on some confusion than on genuine evidence.

2) Jireček (op. cit. 140) gives 7 years to Kormisosh (and 5 to Sevar) in order to make room for the anonymous reign of $28 \mathrm{y}$. after Tervel. The Bulgarian dates disprove this hypothesis decisively. 
more or less than $3 \mathrm{y}$., and that the compiler of the list was aware of this. For instance, if Telets came to the throne in the last months of 4. alem and died near the beginning of 8 . alem, the author, if he knew the fact, would set down his regnal y. as 3. Now we have already observed that the List was probably compiled soon after the date at which it terminates; so that the author would have had personal knowledge not only of the 40 days of Umor, but also of the reigns of Vinekh and Telets. In this latter part of the List (Kormisosh-Omar), therefore, for which he was probably himself responsible, he would not have computed the regnal years mechanically, as in the earlier part of the List. It is therefore quite intelligible that, although Telets's accession year was not 5 . alem, his regnal years were approximately 3 . His year, then, must have been either 4 . alem or 6 . alem. As we have already found dokhs $=6$, we get somor $=4$. Telets must have acceded in the last months of somor alem, and died in the first months of shegor alem, in order that his years should be reckoned as 3. Therefore July-Aug. 763 fell nearer to the beginning than to the end of shegor alem. As A. H. 146 commenced on March 21, 763, and A. H. 142 terminated on April 21, 760, these data are in accordance with the possibility that the Bulgarian lunar year coincided with the Arabic year. E. g., if Telets acceded in March or April 760 and was slain early in July 763, the data are satisfied. Similarly if Kormisosh reigned, e. g., from end of Oct. 743 to end of March 760, his regnal years might be reckoned $17\left(16^{1} / 2\right)$. In any case, these data prove that if the Bulgarian year did not coincide with the Arabic, it began not more than $3^{1 / 2}$ months later than the $\mathrm{A}$. $\mathrm{H}$.

There seems to be a considerable discrepancy between the data of the Regnal List as to the reigns of Vinekh and Umor, and the Greek chronographers. They relate that Vinekh, whom they call $\Sigma \alpha \beta i v o s$, was driven out by the Bulgarians and fled for refuge to Constantinople. Paganos or Baian was set up in his stead, and in A. D. 764-5 Sabinos is still at the Imperial court and Paganos sends an embassy to the Emperor (Theophanes, A. M. 6256). Morever Nicephorus (not Theophanes) mentions that Omar was set up by Sabinos (ed. De Boor, 70). From this account, we should have inferred that the reign of Sabinos lasted only a few months, and accordingly Marquart has proposed to read " $\tau$ months" instead of " 7 years" for Vinekh. ${ }^{1}$ ) But in that case his successor's year would not be dilom tutom, but either 8. alem or 9. alem. The significant point is that Pagan or Baian

1) Op. cit. 74 . 
(which is undoubtedly the right form) is not mentioned at all in the Regnal List. This fact, I think, gives us the key. The author of the List was a partisan of Vinekh, and regarded him, even while he was in exile at Constantinople, as the legitimate Khan. His 7 years, therefore, ran from his succession in shegor alem, not to his expulsion, but to his death, probably at Constantinople, in dilom tutom (= A. D. 770). Umor, a member of his family and designate successor, was proclaimed after his death, but sustained for only 40 days. The author, an adherent of the family of Ukil, closes his list with the last of that dynasty.

Besides the Regnal list, and the inscription of Chatalar, there is yet another text in which an event is dated by the old Bulgarian cycle. It is in the Poslieslovie of Tudor, cited by Kalaidovich, Ioannes Exarkh p. 98:

v se ubo lieto (6415) uspe rab bozhii sego kniazia otets . . velikii i chestnyi i blagovennyi gospod nash kniaz' Bolgarsk imenem Boris... Sei zhe Boris Bolgary krestil est' vlieto etkh' bekhti.

Here etkh' bekhti is given as the year of the conversion of the Bulgarians to Christianity, and it is clearly a year in the Bulgarian cycle. The easiest and most obvious restoration seems to be either tokh vechem ( $\boldsymbol{\partial} \chi \boldsymbol{\alpha} \beta \varepsilon \chi \tau \varepsilon \mu$ ) or tek vechem. Let us see whether either of these will yield the right date, which we already know at least approximately.

We have three texts which give us chronological indications as to the conversion of the Bulgarians. (1) Pope Nicolas I writing to Salomon in May 864 says that Lewis the German entertains hopes that the Bulgarian king will embrace Christianity. ${ }^{1}$ ) (2) Hincmar of Reims writes in 864 that Boris had promised to become a Christian. ${ }^{2}$ ) (3) Photios writing in 869 to the Patriarchs and Bishops of the East refers to the Bulgarian embassy to Rome in A. D. 866, and says the Bulgarians were then Christians for less than 2 years ( $\delta v_{0}$ ov $v_{x} \varepsilon l_{S}$ Eviavrovs). ${ }^{3}$ ) These texts agree perfectly in suggesting that the conversion was effected between 864 and 866 .

Now the year tokh vechem corresponds to A. H. 251 which was current from 865 Feb. 2 to 866 Jan. 21; in other words, it gives us 865 as the date of the conversion, and the restoration tolk vechem is justified. This appears to me to be a very striking corroboration of the soundness of the method which I have employed and of the trath
1) Mansi, 15, 457.
2) Pertz, Ss. I 473.
3) Epistolae, p. 1651 ed. London. 
of my hypotheses. Had my reconstruction of the chronological cycle been merely an ingeniously built castle in the air, how enormous were the chances against such a coincidence as that an isolated record like this should yield, under my false interpretation, precisely the date required!

III.

The values of the Bulgarian numerals, as determined by the foregoing investigation, are as follows ${ }^{1}$ ):

1 vereni
2 dvansh (or dvan)
3 tokh
4 somor
5 dilom
6 dokhs
7 -
8 shegor

9 tek (?)

10 ekhtem (or shekhtem)

20 al'tom

30 trirem

40 vechem

50 alem

60 tutom

The following table embodies our chronological results. The dates are the accession years of the khans:

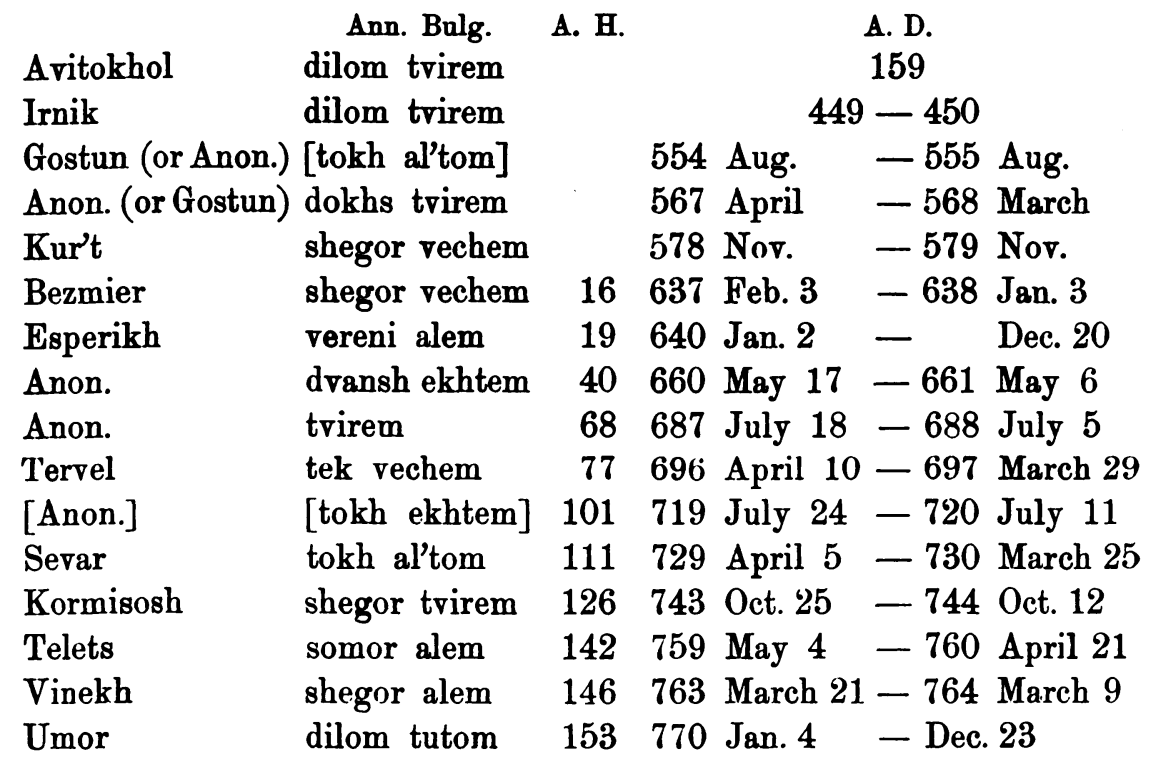
Crossing of the Danube (Bulgarian era): vereni ekhtem: A. H. 39: A. D. 659 Mai $29-660$ May 16.

1) It may be noticed now that two of the numerals lend themselves to obvious Turkish comparisons: shegor: säkiz 8 and alem: älir 50. Other possible connexions are: vereni: bir 1; tek: tokuz 9; tvirem: o-tuz 30. 
Building of Preslav (inscription of Chatalar): shegor alem : A. H. 206: A. D. 821 June $6-822$ May 26.

Conversion of Bulgarians to Christianity: tokh vechem: A. H. 251: A. D. 865 Feb. 2 - 866 Jan. 21.

Finally, I offer a revised text of the Regnal List:

Avitokhol zhit lie $\boldsymbol{\tau}^{\prime}$. rod emou doulo. a lie emou dilom trirem.

Irnik

Gostun zhit $\operatorname{lie}^{t} \varrho^{\prime}$ i $\eta^{\prime}$ liet. rod emou doulo. a lie emou dilom trirem. * namiestnik syi. 〈 $\gamma^{\prime}$ lie$^{t}$. rod emou *. a lie emou tokh al'tem. namiestnik syi.> $\beta \iota^{\prime}$ lie $e^{t}$ rod emou ermi. a lie emou dokhs trirem.

Kourst $\xi^{\prime}$ lie drøzha. rod emou doulo. a lie $e^{t}$ emou shegor rechem. Bezmier $\quad \gamma^{\prime}$ liet. a rod emou doulo. a lie $^{t}$ emon shegor vechem.

sii $\left[\varepsilon^{\prime}\right]$ kъnAzb drızhashe knAzhenie obonu stranou dunaia $\operatorname{lie}^{t} \varphi^{\prime}$ i $\varepsilon \iota^{\prime}$ ostrizhenami glavami. i potom pride na stranou dunaia Isperikh knzı tozhde i doselie.

Esperikh knzb. $x^{\prime}$ i odino lieto. rod emou doulo. a lie ${ }^{t}$ emou vereni alem. $\left\langle{ }^{*}\right\rangle \quad x^{\prime}$ i $\eta^{\prime}$ liet. rod emou doulo. a lie ${ }^{t}$ emou dvansh ekhtem. 〈* $\boldsymbol{v}^{\prime} \operatorname{lie}^{\mathrm{t}}$. rod emou doulo. a lie $e^{\mathrm{t}}$ emou $\rangle$ trirem.

Tervelb $\quad x^{\prime}$ i $\delta^{\prime}$ liet. rod emou doulo. a lie emou tek vechem.

〈* $\quad i^{\prime} \operatorname{lie}^{t}$. rod emou doulo. a lie ${ }^{t}$ emou tokh ekhtem〉.

Sevar $\varepsilon \iota^{\prime}$ liet. rod emou vokilb. a lie ${ }^{t}$ emou tokh al'tom.

Kormisoshb $\xi^{\prime}{ }^{\prime}$ lie$^{t}$. rod emou vokilb. a lie ${ }^{t}$ emou shegor tvirem.

sii zhe knzь izmienie rod doulov, rekshe vikhtuns.

Teletsı $\quad \gamma^{\prime}$ liet. rod emou ougain. a $\operatorname{lie}^{t}$ emou somor alem.

i sii inogo rad.

Vinekh $\xi^{\prime}$ liet. a rod emou oukilb. $\left\langle a \operatorname{lie}^{t}\right\rangle$ emou shegor alem.

Oumor $\quad \mu^{\prime}$ dnii. rod emou oukilb. a $\left\langle\operatorname{lie}^{\natural}\right\rangle$ emou dilom toutom.

I am fully conscious that the reconstruction which I have offered of the period between Esperikh and Sevar is exceedingly problematical. The corruptions in this portion of the text render a certain restoration impossible, till new evidence be forthcoming. But this defect does not invalidate the general results at which I have arrived by a process of investigation entirely immune (I take the liberty of insisting on this point again) from assumptions based on linguistic comparisons.

Cambridge.

J. B. Bury.

P. S. It is possible that a Bulgarian date stood in the last line of the mutilated Eski-Juma inscription published in Aboba, 226. The tops of the four letters which are visible point to exovov, and I suggest that this may be read $\varepsilon v 0 v(s) \circ b[\varepsilon \tau \chi \varepsilon \mu]=$ in the year vechem, referring to A.D. 814. A vechem year fell in A. D. 813/4. I will deal with this inscription elsewhere. 